\title{
The role of Open-book Management in Achieving Organizational Agility "Research based on PhD. Thesis"
}

\author{
${ }^{1}$ Mohammed A. Hussein Al-Taii, ${ }^{2}$ Hadi Kh. Ismael, ${ }^{3}$ Shihab A. Khudhur \\ ${ }^{1}$ Banking \& Finance Department, Zarka University, Jordan \\ 2,3Banking \& Finance Department, Duhok Polytechnic University, Kurdistan Iraq
}

\begin{abstract}
The study aims at acknowledging the impact of Open-book management on the types of organizational agility (sensing agility, decision-making agility, and acting agility) in the private universities / Kurdistan Region - Iraq. The study has used the analytical descriptive methodology, through using questionnaire to collect information from the members of the university councils in (11) private university in Kurdistan Region - Iraq. The sample of the study includes (91) members of the university councils. The statistical program (SPSS. V. 21) has been used to analysis the information collected and to get the results of the hypotheses testing.

The main findings of the study were that the surveyed universities are practicing both of open-book management and organizational agility at high levels. The study also indicates that open-book management has a significant impact on organizational agility at the surveyed universities. A number of suggestions were presented focusing on that the private universities need to pay more attention to practice open-book management as it has a positive significant impact on achieving organizational agility.
\end{abstract}

Keywords: Open-book management, organizational agility, sensing agility, decision-making agility, acting agility.

\section{Introduction}

Currently, most organizations are under tremendous pressure to work in a dynamic environment, with continually changing volatile events that have a great influence on the organization (Saha, et al.,2017: 323334). These changes require organizations to revise their strategic priorities and visions. The organizational agility is one of the methods for responding to these changes and revolution factors (Nafei ,2016: 296-309).

Indeed, the organizational agility is a modern concept in contemporary administrative through which all organizations, including universities, can achieve survival and prosperity in a competitive environment full of constant and unpredictable change, through

Academic Journal of Nawroz University

(AJNU) Volume 9, No 1 (2020).

Regular research paper : Published 26 March 2020

Corresponding author's e-mail : mohammedabdi@gmail.com

Copyright $@ 2018{ }^{1}$ Mohammed Abid Hussein Al-Taii, ${ }^{2}$ Hadi Khalil Ismael, 3Shihab Ahmed Khudhur. This is an open access article distributed under the Creative Commons Attribution License. rapid and effective response to changing in environmental factors.

On the other hand, in the recent years, a growing number of the organizations have been experimenting with an innovative management philosophy known as open-book management. The basis of open-book management is that the information gained by the staff should not only help them to do their jobs but also should be beneficial for their understanding of the overall performance of the organization .

Based on the above, the current study is designed to diagnose the role of the open-book management in achieving organizational agility. The private universities in the Kurdistan Region - Iraq were select as a field of study. The study included five parts, the first devoted to the methodology, the second presents the theoretical framework for the study variables, the third presents the results of the study, the fourth is 
devoted to the discussion of the results, and the fifth presents the conclusions and suggestions.

\section{METHODOLOGY}

\subsection{The Problem of The Study}

The study finds the problem of the study through two sources. The first source is to be found in the literature, where literature refers to the problem facing contemporary organizations, which is the need of these organizations for organizational agility as a successful application for responding to the rapid change and environmental complexity (Sharifi and Zhang, 2001:772-794; Yeganegi, and Azar 2012 :3-6; Nafei,2016: 297-309). The second source is found in previous studies, and it turns out that a lack in the number of previous studies that deals with the analysis of the relationship between open-book management and organizational agility at universities sector. This lack called for the researcher to test the role of open-book management on achieving organizational agility at the private universities sector in Kurdistan Region - Iraq. More specifically, the study investigate the following questions:

a. What is the level of practicing open-book management in the surveyed universities?

b. What is the degree of organizational agility in the surveyed universities?

c. To what extent open-book management is related to organizational agility in the surveyed universities?

d. How does open-book management impact the organizational agility in the surveyed universities?

\subsection{Importance of the Study}

The academic importance of the current study stems from it being contributing to literature that focuses on two important topics in management literature, namely open-book management and organizational agility. The importance of this study comes also through it is being considered as one of few researches that examined the relationship between open-book management and organizational agility in the context of private universities sector in the Kurdistan Region - Iraq. The field importance of the current study is that the surveyed universities can benefit from the results of the study in enhancing their level of practicing open-book management, and organizational agility.

\subsection{Objectives Of The Study}

a. Measuring the level of practicing open-book management in the survived universities.

b. Measuring the degree of organizational agility in the survived universities.

c. Determining the relationship between open-book management and organizational agility in the survived universities.

d. Identifying the impact of open-book management on organizational agility in the survived universities.

e. Providing a set of suggestions to enhance the levels of practicing open-book management and organizational agility in the survived universities.

\subsection{The Hypotheses Of The Study}

The following are the hypotheses of the study , and it will be tested at $(\alpha \leq 0.05)$ level of significant

- H1: There is statistically significant relationship between open-book management and organizational agility in the surveyed universities. From the first main hypothesis there are three subhypotheses as follows:

H1: There is a statistically significant relationship between open-book management and sensing agility in the surveyed universities.

$\mathbf{H 1}_{2}$ : There is a statistically significant relationship between open-book management and decisionmaking agility in the surveyed universities.

$\mathbf{H 1}_{3}$ : There is a statistically significant relationship 
between open-book management and acting agility in the surveyed universities.

- H2: There is a statistically significant impact of open-book management on organizational agility in the surveyed universities.

From the second main hypothesis there are three sub-hypotheses as follows:

- $\mathbf{H 2} \mathbf{2}_{\mathbf{1}}$ : There is a statistically significant impact of open-book management on sensing agility in the surveyed universities.

- $\quad$ H2$_{2}$ : There is a statistically significant impact of open-book management on decision-making agility in the surveyed universities.

- $\quad \mathbf{H} 2_{3}$ : There is a statistically significant impact of open-book management on acting agility in the surveyed universities.

\subsection{The Proposed Scheme}

Figure (1) shows the proposed scheme of the study, which includes two main variables : the first is openbook management as independent variable and it consists of four principles ( information sharing , training, empowerment, and sharing the results). The second is organizational agility as a dependent variable, and it consists of three dimensions (sensing agility, decision-making agility, and acting agility.

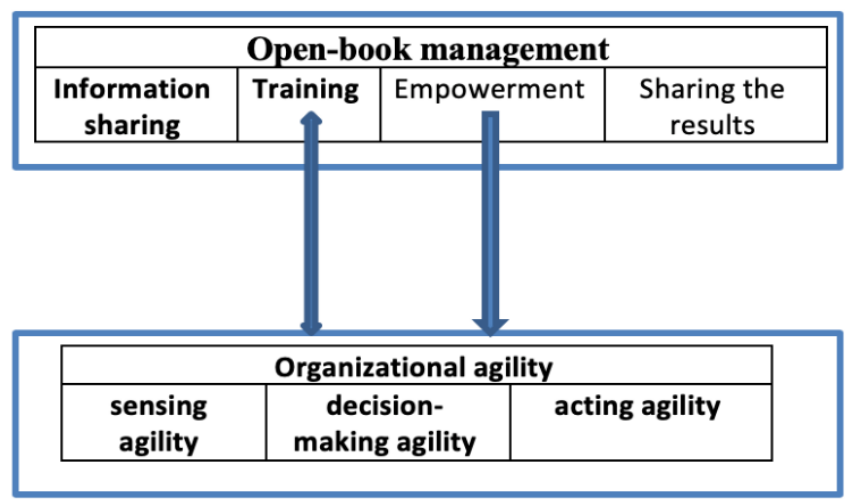

Impact

Correlation

Figure (1): The proposed scheme of the study

\subsection{Data Collection Instrument}

Primary data for this study were gathered from respondents using a questionnaire consists of three basic parts are as follows: First part looked at the demographic characteristics of respondents, the second part is devoted to measuring open-book management , while the third part is devoted to measuring organizational agility. Open-book management was assessed using a questionnaire consists of (28) items , this instrument has been adapted from many previous instruments (Aggarwal and Simkins 2001; Nikzad and Maryam 2012) . Organizational agility was assessed using a questionnaire consist of (21) items, this instrument has been adapted from previous measurements (Nafei ,2017: 297-309 ; Park, 2011:28-38; Thao,2012: 36)

Respondents in this study rated each item on a 5-point Likert scale ranging from strongly disagree (1) to strongly agree (5).

In order to ascertain the ability of the questionnaire to measure the variables of the study, reliability of the questionnaire was measured using the Cronbach Alpha Coefficient. The values of Cronbach's alpha were (0.92) at the total level of the scale, (0.95) for open-book management, and (0.89) for organizational agility, thus, it can be concluded that the measures have an acceptable level of reliability.

To ensure that the collected data follow the normal distribution for statistical analysis, using the Kortbashov equation. The results of the analysis shows that the calculated values of P-Value were (0.464) and (0.752) for open-book management and organizational agility respectively. Both values are higher than the value of the mean value of the study (0.05), Thus, the collected data follow the normal distribution, and the conditions of statistical analysis can be applied to them.

\section{THEORETICAL FRAMWORK}

\subsection{The Concept And Principles Of Open-Book}

\section{Management}


The concept open-book management was coined by Jack Stack who wrote the book " The Great Game of Business." He refers to open-book management as follows: "The Great Game of Business is all about promoting clear, effective and open communication in a company " (Kidwell and Scherer, 2001:113-1124). According to (Nikzad and Maryam: 2011: 342) openbook management is "the distribution and sharing of financial information, production processes, quality reports and customer service between the organization and its human resources". (Weinzweig, 2016: 1) refers it as " a means participation all information on the work of the Organization with all human resources in the organization ". (Weinzweig, 2016: 1).It was also defined as "a practice that make an organization's financial data and performance available for employees in order to be aware of its financial position" ( Alkhamis ,2018:157). The basis of open-book management is that the information received by employees should not only help them do their jobs effectively, but help them understand how the company is doing as a whole. (Kidwell and Scherer, 2001:113-1124). The benefits of open-book management include improving employee performance, enhancing employee knowledge and expertise, improving open communication, giving employees the opportunity to contribute to organizational goals, boosting employee creativity, and making better customer satisfaction (Al-Mzary et al. 2015: 128-140 ; Groen et al. 2016: 51-66 ; Padmasiri et al. $2018: 13-17)$.

The importance of application open-book management is everyone can see what happens in organizations that follow an open-book management approach, and make employees involved in assuming responsibility instead of evading them. It is the means to hold everyone accountable at work, and to record all information on the implementation and completion of the work
(Ambur, 2003: 14). The application of open-book management practices also allows all employees in the organization to participate in doing business, and helps to improve the performance of all levels of management by enabling employees with the information they need to make the right decisions and the ability to act (Broughton and Thomas, 2012: 8-10).

Regarding the Principles of open-book management, it is clear through literature review that researchers agreed that the application of open management involves four sequential and interrelated steps, and these steps are the basic principles of open-book management ,Which are (Nikzad and Maryam, 2012: 341; Aggarwal and Simkins, 2001: 24; Alkhamis, 2018:158 )

\section{A. Information sharing (Get the information out} there): Open-book management is the sharing of information required by employees to make sound business decisions that are right for the ensured success of the organization and its future through meeting agreed-upon organizational goals .The technique is to tell employees not only what they need to know to do their jobs effectively, but also how the division or the organization as a whole is doing. In essence, reduce the internal differences between the information available to owners and management and that available to lower-level employees, so they can make better decisions.

\section{B. Training (Training employees to understand the} basics of performance measures): The decision to convert to open-book management requires a serious and ongoing commitment from management and employees to engage in continuing training. Training is required for information analysis, this enables the employees to apply what they are learn to see the effect they can have on an established goal, allowing employees to 
use the knowledge they have gained to affect an established goal, and strengthens their commitment to the process and helps provide a sense of ownership.

\section{Empowerment (Empower employees to make decisions based on what they know) : The philosophy of open management is that employees are empowered in their decision-making capacity based on acquired information, which should not only help their work but also should be useful for their understanding of the overall functioning of the organization .}

D. Sharing the results (Make sure everyone shares directly in the organization's success and failure) : Open-book management bonus systems vary widely, but the overall message is the same: "Reward employees for business success". Traditional bonus systems do a poor job of communicating this critical link. In fact, employees often begin to expect the annual bonus and view it as a regular part of their compensation. Open-book bonuses, in contrast, are pegged to numbers that employees see regularly, numbers they understand and on which they know they have an impact.

Based on the above and consistent with the current trends of the study, the researchers define the openbook management procedurally as : A philosophy adopt by the academic leaders at the university to encourage employees to achieve the university goals, and ensure its success, through sharing information with employees, training them to understand the shared information, empowerment them to make decisions based on what they know, and their participation in all cases of success or failure of the university.

3.2 The Concept and Dimensions Of Organizational Agility
Most authors and researchers look at the concept of organizational agility as a specific set of organizational sense-response actions that are typical for organizations operating in an environment characterized by turbulence, unpredictability, and rapid change (Nadkarni and Narayanan,2007: 245). According to (Tallon, and Pinsonneault ,2011: 464) conceptualize agility is an organizational ability to "detect and respond to [environmental] opportunities and threats with ease, speed, and dexterity. According to (Yeganegi, and Azar, 2012: 2538) who define organizational agility is the ability of the organization to respond quickly and successfully to environmental changes (Sanadgol 2014: 317) defines organizational agility as the ability of the organization to move quickly, effectively, easily, and think quickly with a smart way of meeting business requirements (Madeleine and Louise ,2018 : 32) define organizational agility as an "emerging management concept" that prepares the organization to make rapid decisions in the dynamic and unpredictable market dominating today.

Regarding the importance of organizational agility, (Nafie ,2016:298) state that organizational agility enables the organization to carry out a series of specific tasks successfully, in addition to managing the opportunities and risks in the business activities effectively. Organizational agility is not only "flexible" to employments for predictable changes but also is able to respond and adapt to unpredictable changes quickly and efficiently (Oosterhout et al., 2006:132-145).

Regarding the dimensions of organizational agility, it is clear through literature review that researchers agreed on three dimensions of organizational agility which are: sensing agility, decision-making agility, and acting agility (Nafei ,2017: 297-309 ; Park, 2011:28-38; Thao.2012: 36). 
A. Sensing agility: The sensing agility is the organizational capacity to inspect and monitor events and changes in the surrounding environment (customer preferences changes, the movements of the new competitors, new technology) in a timely manner (Park, 2011:28-38). (Thao.2012: 36) refers to Sensing Agility as the capacity of organization to access the information that enables them to adapt for changes quickly, through a systematic environmental survey.

B. Decision-Making Agility: The decision-making agility is the ability to collect, accumulate, restructure and evaluate relevant information according to a variety of sources to explain the implications of the business without delay, and to identify opportunities and threats based on the interpretation of events, along with the development of action plans, which direct the reconfiguration of resources and the development of new competitive procedures (Nafie,2016:299).

C. Acting Agility: The acting agility includes a set of activities for re-assembling organizational resources and modifying business processes on the basis of the principles of work resulting from the task of decision-making in order to address the change that occur in the surrounding environment (Eisenhardt \& Martin,2000). The acting agility provides organizations with the needed speed in responding to emerging new opportunities in the business environment, with acting agility organizations can increase the effectiveness of their operations through the purposeful translation of opportunities into adequate actions (Holotiuk et al.,2018:4)

The researchers introduce the procedural definition of organizational agility as : The ability of the university to respond and adapt quickly and successfully to environmental changes through sensing agility, decision-making agility, and acting agility.

\subsection{The Theoretical Relationship Between Open-Book Management And Organizational Agility}

Open-book management helps to successfully implement a range of organizational agility activities by sensing the diagnosis of opportunities, responding to the organization and reflecting threats to its various activities, which in turn enables the organization to create new innovations in a timely manner (Ardichvile,et al., 2003:105-123). Open-book management practices also increase the organization's ability to respond quickly to environmental change, achieve success, exploit market opportunities and respond to threats in a timely manner (Houghton, et al. 2004: 20-21).

According to :(Park, 2011: 26) The practicing of open management in an organization contributes to interaction with a rapidly changing and unpredictable environment through the following:

A. Sensing: Changes and events are captured by information systems owned by organizations.

B. Decision Making Process : If decision makers receive alerts or find exceptions, they begin analyzing data (data flow) and finding patterns that explain why the jump is changing. It identifies opportunities or threats as an integral part of making business principles to maximize the impact of opportunities and minimize the impact of threats. Diagnose basic design criteria, and identify several sets of key standards.

C. Acting : Based on the principles of work, as there can be designs and changes in consumer purchasing behaviors, presentations, procedures, and various options. Modify the corresponding business processes to support in the current product modification and introduce new and innovative products reflecting changing market 
trends over time, the cycle of creating innovation with continuous testing.

\section{RESULTS}

\subsection{The Demographic Profile Of The Respondents}

The subject of the study is member of the private universities councils in Kurdistan Region / Iraq. The number of private universities in the Kurdistan Region is (19) university during the academic year 2018/2019. The questionnaire was distributed to all members of the university councils in (11) universities, (8) universities were excluded due to the inexistence of the council members to complete the questionnaire. A total of (107) questionnaires were distributed, (91) were valid i.e. (85 $\%$.), table (1) shows the distribution of respondents according to the surveyed universities, and tables (2) shows the profile of the respondents.

Table (1): The distribution of respondents within surveyed universities

\begin{tabular}{|l|l|c|c|}
\hline No. & \multicolumn{1}{|c|}{ Universities Names } & $\begin{array}{c}\text { Number of } \\
\text { distributed } \\
\text { questionnaire }\end{array}$ & $\begin{array}{c}\text { Number of } \\
\text { Valid } \\
\text { Questionnaire }\end{array}$ \\
\hline 1 & $\begin{array}{l}\text { International University } \\
\text { Erbil }\end{array}$ & 9 & 6 \\
\hline 2 & Ishik University- Erbil & 11 & 10 \\
\hline 3 & Bayan University & 8 & 7 \\
\hline 4 & Cihan University- Erbil & 23 & 22 \\
\hline 5 & $\begin{array}{l}\text { Cihan University- } \\
\text { Duhok }\end{array}$ & 7 & 6 \\
\hline 6 & $\begin{array}{l}\text { Cihan University- } \\
\text { Sulaimani }\end{array}$ & 7 & 6 \\
\hline 7 & $\begin{array}{l}\text { Lebanese French } \\
\text { University }\end{array}$ & 8 & 7 \\
\hline 8 & Nawroz University & 8 & 5 \\
\hline 9 & Knowledge University & 10 & 7 \\
\hline 10 & Catholic University & 5 & 91 \\
\hline 11 & $\begin{array}{l}\text { Komar University of } \\
\text { Science and Technology }\end{array}$ & 9 & 67 \\
\hline Total & 107 & \\
\hline
\end{tabular}

Source: Analyzing questionnaire data

Table (2): Demographic profile

\begin{tabular}{|l|l|c|c|}
\hline \multicolumn{1}{|c|}{ Variables } & \multicolumn{1}{|c|}{ Descriptions } & Freq. & \% \\
\hline \multirow{2}{*}{ Gender } & Male & 87 & 95.6 \\
\cline { 2 - 4 } & Female & 4 & 4.4 \\
\hline \multirow{4}{*}{ Age } & Below 30 years & 20 & 22 \\
\cline { 2 - 4 } & Above 30 years-45 years & 21 & 23 \\
\cline { 2 - 4 } & Above 45 years & 50 & 55 \\
\hline \multirow{2}{*}{$\begin{array}{l}\text { Academic } \\
\text { qualification }\end{array}$} & Master & 26 & 28.6 \\
\cline { 2 - 4 } & Doctoral & 65 & 71.4 \\
\hline Scientific title & Assistant Lecturer & 16 & 17.6 \\
\hline
\end{tabular}

\begin{tabular}{|l|l|c|c|}
\hline \multirow{4}{*}{ Current position } & Lecturer & 26 & 28.6 \\
\cline { 2 - 4 } & Assistant Professor & 42 & 46.1 \\
\cline { 2 - 4 } & Professor & 7 & 7.7 \\
\cline { 2 - 4 } & $\begin{array}{l}\text { Lecturer representative } \\
\text { department dean ,head }\end{array}$ & 6 & 6.6 \\
\cline { 2 - 4 } & Vice president of university & 9 & 79.1 \\
\cline { 2 - 4 } & President of university & 4 & 4.9 \\
\hline $\begin{array}{l}\text { number of years } \\
\text { respondents have }\end{array}$ & Below 3 years & 52 & 57.1 \\
\cline { 2 - 4 } $\begin{array}{l}\text { been working in years } \\
\text { the current } \\
\text { position }\end{array}$ & above 7 years & 28 & 30.8 \\
\hline $\begin{array}{l}\text { number of years } \\
\text { respondents have } \\
\text { been working in } \\
\text { the higher } \\
\text { education sector }\end{array}$ & Below 5 years & 11 & 12.1 \\
\cline { 2 - 4 } & 5-10 years & 12 & 13.2 \\
\hline above 10 years & 73 & 81.2 \\
\hline
\end{tabular}

Source: Results of SPSS

\subsection{Descriptive Statistics}

To determine the levels of Open-book management and the organizational agility in surveyed universities, mean values were calculated and categorized into three levels which are: low (Mean values equal or less than 2.34), moderate (Mean values between 2.34 and less than 3.67), and High (Mean values of 3.7 or higher). Standard deviation used for measuring the dispersion of a set of data from its Mean, whereas Coefficient of agreement used for ranking. The results were as follows:

\subsubsection{Descriptive Statistics Of Open-Book Management}

Table (3) shows the mean and standard deviation and Coefficient of Agreement for open-book management. . In general, the table reveals that the majority of the respondents agree that open-book management(overall), is practiced at high level in the surveyed universities (mean $=3.79$, Standard Deviation $=0.91$ coefficient of agreement $=\% 76$ ). The highest importance level was for sharing the results (Mean $=3.86$, Std. Deviation $=0.90$, coefficient of agreement $=\% 77$ ). Which indicates that the majority of the respondents agree that sharing the results is 
practiced at high level in the surveyed universities. The lowest importance level was for the information sharing,$($ Mean $=3.61$, Std . Deviation $=0.93$, coefficient of agreement $=\% 74)$, which indicates that the majority of the respondents agree that information sharing is practiced at moderate level in the surveyed universities.

Table (3): Descriptive statistics of open-book management

\begin{tabular}{|r|r|r|r|r|r|r|}
\hline No & Items & Mean & SD & CA \% & Level & Ranking \\
\hline 1 & $\begin{array}{r}\text { Information } \\
\text { sharing }\end{array}$ & 3.61 & 0.93 & 74 & $\begin{array}{r}\text { Mod } \\
\text { erate }\end{array}$ & 4 \\
\hline 2 & Training & 3.85 & 0.90 & 77 & High & 2 \\
\hline 3 & Empowerment & 3.82 & 0.90 & 76 & High & 3 \\
\hline 4 & Sharing the results & 3.86 & 0.90 & 77 & High & 1 \\
\hline $\begin{array}{l}\text { Open-book } \\
\text { management(over all) }\end{array}$ & 3.79 & 0.91 & 76 & High & ------ \\
\hline
\end{tabular}

Source: Results of SPSS

\subsubsection{Descriptive Statistics of Organizational Agility}

Table (4) manifests the Mean, standard deviations and Coefficient of agreement for the organizational agility and the three dimensions of organizational agility (sensing agility, decision-making agility, and acting agility) in the surveyed universities from the universities boards' view. In general, the table reveals that the majority of the respondents agree that organizational agility (overall), is practiced at high level in the surveyed $($ Mean $=3.92$, std. $=0.80$, Coefficient of Agreement $=\% 80$ ), and the level of sensing agility, decision-making agility, acting agility were also high .The highest importance level was for decision-making agility with $($ Mean $=3.96$, Std $=0.75$, coefficient of Agreement $=\% 81$ ) . The lowest importance level was for the sensing agility with (Mean $=3.89$, std . $=0.82$, Coefficient of Agreement $=\% 79$ )

Table (4): Descriptive statistics of organizational agility

\begin{tabular}{|l|l|c|c|c|c|c|}
\hline No. & Variables & Mean & SD & $\begin{array}{l}\text { CA } \\
\%\end{array}$ & Level & Ranking \\
\hline 1 & Sensing agility & 3.89 & 0.82 & 79 & High & 3 \\
\hline 2 & $\begin{array}{l}\text { Decision-making } \\
\text { agility }\end{array}$ & 3.96 & 0.75 & 81 & High & 1 \\
\hline 3 & Acting agility & 3.91 & 0.83 & 79 & High & 2 \\
\hline 4 & $\begin{array}{l}\text { Organizational } \\
\text { agility (over all) }\end{array}$ & 3.92 & 0.80 & 80 & High & ------ \\
\hline
\end{tabular}

Source: Results of SPSS

\subsection{Correlation Analysis}

A correlational research design was used as the study is intended to test the first hypothesis of the study, and the results of the correlation analysis are summarized in table (5). The results reveal that open-book management is highly correlated with organizational agility, Sensing agility, Decision-making agility, and acting agility at level $(p<0.01)$. The results of the analysis in Table (5) also show that the four dimensions of open-book management (Information sharing , training, empowerment, sharing results) are highly correlated with organizational agility, Sensing agility, Decision-making agility, and acting agility at level $(\mathrm{p}<$ $0.01)$. The highest value of correlation coefficient ( $R=$ 0.708 ) is between empowerment, and organizational agility. The lowest value of correlation coefficient $(\mathrm{R}=0.596)$ is between Information sharing and organizational agility.

Table (5): Results of correlation analysis

\begin{tabular}{|l|c|c|c|c|}
\hline Variables & $\begin{array}{l}\text { Sensing } \\
\text { agility }\end{array}$ & $\begin{array}{l}\text { Decision- } \\
\text { making } \\
\text { agility }\end{array}$ & $\begin{array}{l}\text { Acting } \\
\text { agility }\end{array}$ & $\begin{array}{l}\text { Organizational } \\
\text { agility(over all) }\end{array}$ \\
\hline $\begin{array}{l}\text { Information } \\
\text { sharing }\end{array}$ & $.540^{* *}$ & $.527^{* *}$ & $.617^{* *}$ & $.596^{* *}$ \\
\hline Training & $.658^{* *}$ & $.614^{* *}$ & $.671^{* *}$ & $.688^{* *}$ \\
\hline Empowerment & $.669^{* *}$ & $.618^{* *}$ & $.711^{* *}$ & $.708^{* *}$ \\
\hline Sharing results & $.645^{* *}$ & $.605^{* *}$ & $.664^{* *}$ & $.678^{* *}$ \\
\hline $\begin{array}{l}\text { Open-book } \\
\text { management } \\
\text { (over all) }\end{array}$ & $.713^{* *}$ & $.671^{* *}$ & $.757^{* *}$ & $.758^{* *}$ \\
\hline
\end{tabular}

** Correlation is significant at the 0.01 level (1-tailed), $\mathrm{n}=91$. Source: Results of SPSS

According to the results of correlation analysis, the first main hypothesis and the three sub-hypotheses that derived from the main first hypotheses were accepted .

\subsection{Regression Analysis}

For the purpose of testing the second hypothesis of the study, a set of simple regression analyses were used. The first simple regression analysis was carried out to find out the extent to which the values of organizational agility is explained by open-book management, so it is 
depended on $\mathrm{R}^{2}$. Table (6) demonstrates the results . According the results $58 \%$ of the variance in the values of organizational agility is explained by open-book management $\left(R^{2}=0.58\right)$, and the rest of the percentage $(42 \%)$ is explained by other variables. The regression model is significant $(F=120, p=0.000)$.

Table (6): Results of regression analysis

\begin{tabular}{|c|c|c|c|c|c|c|}
\hline Model & $\begin{array}{l}\text { Sum of } \\
\text { Squares }\end{array}$ & Df. & $\begin{array}{c}\text { Mean } \\
\text { Square }\end{array}$ & $\mathbf{R}^{2}$ & $\mathbf{F}$ & Sig. \\
\hline Regression & 18.340 & 1 & 18.340 & \multirow{3}{*}{0.58} & \multirow{3}{*}{120} & \multirow{3}{*}{$.000^{\circ}$} \\
\hline Residual & 13.568 & 89 & .152 & & & \\
\hline Total & 31.908 & 90 & & & & \\
\hline
\end{tabular}

Dependent variable: Organizational agility, F tab. $(1,89)=3.96$

Source: Results of SPSS

The second regression analysis was to determine the impact of open-book management as independent variable on sensing agility, decision-making agility, and acting agility as dependent variables, and the results are summarized in table (7) as follows:

A. There is a statistically significant impact of openbook management on sensing agility, in the surveyed university ( $\left.\mathrm{t}=9.585, \mathrm{R}^{2}=.51, \mathrm{~F}=91\right)$.

B. There is a statistically significant impact of openbook management on decision-making agility, in the surveyed university $\left(\mathrm{t}=8.546, \mathrm{R}^{2}=.45, \mathrm{~F}=73\right)$.

C. There is a statistically significant impact of openbook management on decision-making agility, in the surveyed university $\left(t=10.917, \mathrm{R}^{2}=.57, \mathrm{~F}=119\right)$

D. According to (Beta) values, the strongest impact of open-book management appeared on acting agility (Beta $=0.757)$, while the weakest impact of open-book management appeared on decision-making agility $($ Beta $=0.671)$.

Table (7): Results of regression analysis between study variables

\begin{tabular}{|l|c|c|c|c|c|c|}
\hline $\begin{array}{l}\text { Dependen } \\
\text { t variables }\end{array}$ & \multicolumn{2}{|c|}{$\begin{array}{c}\text { Unstandardize } \\
\text { d Coefficients }\end{array}$} & $\begin{array}{c}\text { Standardize } \\
\mathbf{d} \\
\text { Coefficients }\end{array}$ & T & $\mathbf{R}^{2}$ & $\mathbf{F}$ \\
\cline { 2 - 5 } & $\mathbf{B}$ & $\begin{array}{c}\text { Std. } \\
\text { Error }\end{array}$ & Beta & & & \\
\hline $\begin{array}{l}\text { Sensing } \\
\text { agility }\end{array}$ & $\mathbf{0 . 7 9 7}$ & $\mathbf{0 . 0 8 3}$ & $\mathbf{0 . 7 1 4}$ & $9.585^{* *}$ & $\begin{array}{l}0.5 \\
1\end{array}$ & 91 \\
\hline
\end{tabular}

\begin{tabular}{|c|c|c|c|c|c|c|}
\hline \begin{tabular}{|l} 
Decision- \\
making \\
agility \\
\end{tabular} & 0.657 & 0.077 & 0.703 & $8.546^{* *}$ & \begin{tabular}{|l|}
0.4 \\
5
\end{tabular} & 73 \\
\hline $\begin{array}{l}\text { Acting } \\
\text { agility }\end{array}$ & 0.797 & 0.073 & 0.757 & $\begin{array}{l}10.917^{*} \\
*\end{array}$ & $\begin{array}{l}0.5 \\
7\end{array}$ & $\begin{array}{l}11 \\
9\end{array}$ \\
\hline
\end{tabular}

In dependent variable: Open-book management, ${ }^{* *}$ significant at the 0.01 level (1-tailed),

T tab. (D.f. 90) $=1.66, F$ tab. $($ D.f 1,89$)=3.96$

Source: Results of SPSS

According to the results of of regression analysis, the second main hypothesis and the three sub-hypotheses that derived from the main first hypotheses were accepted

\section{DISCUSSION}

This study attempts to investigate the relationship between open-book management and Organizational agility at private universities in Kurdistan region-Iraq. The results of descriptive statistics showed high levels of open-book management which reflects high interest by the academic leaders of the surveyed universities in the application of open-book management principles in those universities .The results of descriptive statistics showed also high level of organization agility, which indicate that the academic leaders of the surveyed university pays enough attention to raising the level of organization agility in those universities.

Based on the results of the correlation analysis between open-book management and organization agility, that have been shown to be significant and positive, it is obvious that the high level of open-book management is associated with the high level of organization agility, and vice versa. This result is in line with the view of (Houghton et al., 2004) who state that open-book management practices increase the level of organization's sensing agility through the increasing of organization's ability to respond quickly to environmental change, market opportunities, and threats, in a timely manner .

According to the results of regression analysis, openbook management has significant impact on 
organization agility, this means open-book management is one of the predictors of organizational agility. This result provides a clear message to university council members that if they want to achieve organizational agility at their universities, they should focus their attention on the applications of open-book management principles. This result is consistent with the view of (Ardichvile et al., 2003) and (Overby, et al. 2006) that open-book management helps to successfully implement a number of activities within organizational agility, including rapid response to environmental change , exploitation environmental opportunities, and timely response to threats.

The results of regression analysis show that $(58 \%)$ of the variance in the values of organization agility is explained by open-book management. This result reflects the importance of open-book management in achieving organizational agility, and this result is in line with the view of (Park, 2011) who state that the practicing of open management in an organization contributes to interaction with a rapidly changing and unpredictable environment through sensing, decision making process, and acting .

The results of this study also show that the impact of open-book management on acting agility was stronger than the impact of open-book management on decision making agility and sensing agility (based on Beta values). This means that open-book management maintenance could predict acting agility greater than the prediction of decision making agility and sensing agility.

\section{CONCLUSIONS AND SUGGESTIONS}

\subsection{Conclusions}

- The results showed that the application of openbook management principles in the surveyed universities was at high levels, which reflects the great interest of universities academic leaders in applying information sharing, employee training , employee empowerment, and sharing the results .

- There is a clear tendency among the respondents to agree on the existence of high level of organizational agility in the surveyed universities , and concluded that the surveyed universities have high level of the ability to respond and adapt quickly and successfully to environmental changes through sensing agility, decision-making agility, and acting agility .

- One of the important findings of the current study was the ranking of the principles of open-book management according to priority and importance as follows: Sharing the results, training, empowerment and, finally, information sharing. Which indicate that members of university council focusing on sharing the results principle more than the others principles of open-book management.

- The ranking of the dimensions of organizational agility in terms of importance areas follows: The Decision-making agility, acting agility and, finally , acting agility. Which confirms the importance of decision-making agility for the members of university council.

- The study proved that there is a statistical positive significant relationship between open-book management and organizational agility ; therefore, high levels of organizational agility are associated with universities whose academic leaders are interested in practicing open-management at high levels, and vice versa.

- Based on the results of the hypotheses testing, open-book management has a statistical positive impact on organizational agility; therefore, the university can increase the degree of organizational agility when they increase the degree of open-book management. 


\section{2 suggestions}

- It is necessary for the private universities to pay attention to the applications of open-book management principles, since they have a great positive impact on the the three types of organizational agility (sensing agility, decisionmaking agility, and acting agility).

2. Increasing the interest of the academic leaders of the universities in information sharing through providing a clear and two-way communication system between academic leaders and, and providing employees not only what they need to know to do their jobs effectively, but also how the the organization as a whole is doing.

- It is necessary for the private universities to pay more attention to sensing agility through building a systematic environmental survey, monitoring changes in the surrounding of the universities environment and the movements of competitors .

- On the ground of the results, suggested interventions to improve organizational agility through open-book management should put empowerment as a first priority since empowerment has the highest correlation with organizational agility.

- Promoting organizational agility in the universities through adaptation and speed responding to unexpected changes in the work environment and delivering innovative solutions.

- Making the best use of the surveyed universities from the current research scale, and the results of field study in enhancing their capacities to adopt the concept of Open- book management and organizational agility.

\subsection{Limitations and Future Researches}

This study was based on the determination of the level of open-book management, and organizational agility from the point of view of the members of university councils, and they are at the top management level, therefore, further research could be conducted to determine these variables from the point of view of the employees in the middle and frontline management of the surveyed universities.

The sample included (11) universities from the total of (18) private universities in the Kurdistan Region, thus there is a need to include the other universities in future studies

The study was limited to the private universities in the Kurdistan Region/Iraq; therefore, similar studies should be undertaken in public universities or outside the higher education sector.

\section{REFERENCES}

\subsection{Scientific Thesis \& Dissertation}

1. Madeleine, Hogfeldt And Louise Lindwall, (2018), Human Resources' Role In An Agile Transformation - A Case Study At Volvo Cars, Master's Thesis In Quality And Operations Management, Chalmers University Of Technology, Gothenburg, Sweden

2. Park, Young Ki, (2011), The Dynamics of opportunité and thread management in turbulent environments: the role information technologies, Degree Doctor of Philosophy (Business Administration Faculty of the USC Graduate School University of Southern California.

\subsection{Journals \& periodical}

1. Aggarwal, R. \& Simkins, B. (2001). Open-book management-optimizing human capital, Business Horizons journal , 44 (5),p. 5-13.

2. Alkhamis, Faisal Abdulkarim , (2018), The Mediating Role Of Employee Job Performance In The Impact Of Open Book Management Dimensions On Customer Satisfaction , Verslas: Teorija Ir Praktika / Business: Theory And Practice , 19: 157165.

3. Al-Mzary M, Al-Rifai A, Al-Momany M (2015) Training and its impact on the performance of 
employees at Jordanian universities from the perspective of employees: the case of Yarmouk University. Journal of Education and Practice 6 p. 128-140

4. Ardichvili, A., Cardozo, R., \& Ray, S., (2003), A theory of entrepreneurial opportunity identification and development, Journal of Business Venturing, 18, p.105-123.

5. Eisenhardt. M. Kathleen and Sull. N. Donald, (2001), Strategy as simple rules, Harvard Business Review, 79(1), p.106-116.

6. Groen BAC, Wouters MJF, Wilderom CPM (2016) Employee participation, performance, metrics, and job performance: a survey study based on selfdetermination theory. Management Accounting Research 36: 51-66.

7. Houghton R., El Sawy O. A., Gray P., Donegan C., \& Joshi A. (2004). Vigilant Information Systems for Managing Enterprises in Dynamic Supply Chains: Real-Time Dashboards at Western Digital, MIS Quarterly Executive, 3(1), p. 19-35.

8. Kidwell, R.E. \& Scherer, P.M. (2001). Layoffs and their ethical implications under scientific management, quality management and open-book management, Journal of Business Ethics 29 (1/2), p.113-124.

9. Nadkarni, S., \& Narayanan, V. K., (2007), Strategic schemas, strategic flexibility, and firm performance: The moderating role of industry clockspeed, Strategic Management Journal, 28(3), p. 234-270.

10. Nafei, Wageedh.A., (2016), Organizational Agility: The Key to Organizational Success, , International Journal of Business and Management; Vol. (11), No. ( 5), p. 297-309.

11. Nikzad, Manteghi \& Maryam, Golkari ,(2012), The Relationship between Open Book Management and
Trust with Organization Financial Performance, Procedia Technology journal , 1,p.340-344.

12. Oosterhout, M. V., Waarts, E., \& Van Hillegersberg, J. (2006). Change Factors Requiring Agility and Implications for it, European Journal of Information Systems, 15(2), p.132-145.

13. Overby, E., Bharadwaj, A., \& Sambamurthy, V. (2006). Enterprise Agility and the Enabling Role of Information Technology, European Journal of Information Systems, 15(2), p.120-131

14. Padmasiri MD, Sandamali JGP, Mahalekamge WGS, Mendis MVS (2018) The relationship between training and development and employee performance of executive level employees in apparel organizations. International Invention of Scientific Journal 2 (01): 13-17.

15. Saha, N., Gregar, A., and Sáha, P. (2017). Organizational agility and HRM strategy: Do they really enhance firms' competitiveness?. International Journal of Organizational Leadership, 6.(3), p.33-334..

16. Sanadgol, Marzie. (2014). The Survey of Relationship between Organizational Agility and Principals Job Satisfaction, International Journal of Sciences \& Applied Research 3, P. 317-319.

17. Sharifi, H., \& Zhang, Z. (2001). Agile Manufacturing in Practice. Application of a Methodology. International Journal of Operations \& Production Management, 21(5/6) , p.772-794.

18. Tallon, Paul P. and Pinsonneault, Alain.( 2011). Competing Perspectives on the Link Between Strategic Information Technology Alignment and Organizational Agility: Insights from a Mediation Model, MIS Quarterly, 35( 2) p.463-486.

19. Thao, t. p., Molla, A., \& Peszynski, K. (2012). Enterprise Systems and Organizational Agility: A Review of the Literature and Conceptual Framework. 
Communications of the Association for Information

Systems, 31(8) , p.167-193.

\subsection{Conference}

1. Holotiuk, Friedrich; Beimborn, Daniel; and Jentsch, Christian,(2018), The Determinants And Role Of Agility In Digital Organizations, Research Papers , Twenty-Sixth European Conference on Information Systems (ECIS2018), Portsmouth,UK,

2. Yeganegi, Kamran and Azar, M., Zahiri, (2012), The Effect of IT on Organizational Agility, International Conference on Industrial Engineering and Operations Management Istanbul, Turkey.

\subsection{Website}

1. Ambur,Owen, (2003), Open-Book Management: Implications for Record-Keeping by Organizations. http://ambur.net/French\&Raven.htm

2. Broughton, A. C. \& Thomas, J., (2012), Embracing Open-Book Management to Fuel Employee Engagement and Corporate Sustainability, UNC Kenan-Flagler Business School. https: www.kenanflagler.unc.edu.

3. Weinzweig, Ari, (2016) , Why Open Book Management is an excellent way to run a business, zing train, httpswww.zingtrain.com.htm. 